\title{
Effect of Deficit Irrigation, Air injection and Nitrogen Fertilization on Water Productivity of Carrot under Subsurface Drip Irrigation System.
}

\author{
Ahmed M.Almoayyad ${ }^{1}$, Mohamed Y.El-Ansary², Montaser A. Awad ${ }^{3}$, AbousrieA.Farag ${ }^{4}$ \\ Ph.D student of Agric. and Bio. Systems Eng. Dep. Fac. of Agric., Moshtohor, Benha Univ. \\ Prof. of Agric. and Bio. Systems Eng. Dep. Fac. of Agric. ,Moshtohor, Benha Univ. \\ Assoc. Prof.of Agric. and Bio. Systems Eng. Dep. Fac. of Agric. ,Moshtohor, Benha Univ. \\ Lecturer of Agric and Bio. Systems Eng Dep. Fac. of Agric., Moshtohor, Benha Univ. \\ Corresponding author: ahmedalmoayyad@gamil.com
}

\begin{abstract}
A field study was conducted in 2017-2018 to evaluate the effect of deficit irrigation, air injection and nitrogen fertilization on yield and water productivity of carrot under subsurface drip irrigation system. Experimental treatments were three levels ofdeficit irrigation $(60 \%, 80 \%$ and $100 \%)$ of full crop water requirements and three types of nitrogen fertilizer(nitric acid(HNO3)48 $\% \quad \mathrm{~N}$, urea $\mathrm{CO}(\mathrm{NH} 2) 246 \% \mathrm{~N}$ and ammonium nitrate(NH4NO3)33.5\% N, with air injection treatment (12\% air by volume of water). The results show that the yield and water productivity as well as the length of carrot root significantly increased for air injection treatments. On the other hand, the carrot diameter increase was not significant. The highest value of the carrot root yield (19.487 ton/fed) was obtained due to deficit irrigation 60\% (I60\%) and ammonium nitrate(NH4NO3)with air injection. Also, treatment of deficit irrigation (I80\%) and urea fertilization $\mathrm{CO}(\mathrm{NH} 2) 2$ with air injection resulted 17.437 (ton/ fed) carrot roots which was significantly higher than that of non-air injection treatments. Also,the highest values of water productivity of carrot were 185.189 and $101.376 \mathrm{~kg} / \mathrm{m} 3 \mathrm{obtained}$ due to(I60\%) with (NH4NO3)and co(NH2)2underair injection treatments, respectively. The highest lengths of carrot $(\mathrm{cm})$ were 19.800 and $19.000(\mathrm{~cm})$ obtained due to $(\mathrm{I} 80 \%)$ with $\mathrm{CO}(\mathrm{NH} 2) 2$ and $(\mathrm{I} 100 \%)$ with $(\mathrm{NH} 4 \mathrm{NO} 3)$, under air injection treatments, respectively. The highest values of carrotdiameter were 42.153 and 41.260 (mm) obtained due to treatment of full irrigation(I100\%) and(NH4NO3) fertilizer withoutair injection and the treatment (I80\%) and $\mathrm{CO}(\mathrm{NH} 2) 2$ fertilizer with air injection, respectively. Data from this study indicate that carrot yield and its water productivity can be improved byaerated sub surface drip irrigation system(SSDI).
\end{abstract}

Key words: Deficit Irrigation, Air injection, Nitrogen Fertilization, Water Productivity.

\section{Introduction}

FAO (2018) indicated that by 2025, 1800 million people are expected to be living in countries or regions with "absolute" water scarcity $(<500 \mathrm{~m} 3$ per year per capita), and two-thirds of the world population could be under "stress" conditions (between 500 and 1000 $\mathrm{m} 3$ per year per capita).In fact, estimates suggests that by 2050 , if we continue with our current approach to water management, global water demand will exceed supply by over $40 \%$, which would put at risk $45 \%$ of global $52 \%$ of the world's population, and $40 \%$ of grain production. This concern is supported by the World Economic Forum that consistently ranks water crises as a top global risk .

Osman et al (2015) indicated that the current economic and population growth as well as the prospective environmental challenges, Egypt is rapidly facing serious water scarcity issue. Water availability per capita rate is already one of the lowest in the world. In 2000, water withdrawal per capita was around $1000 \mathrm{~m} 3$. This is supposed to halve and fall below the scarcity rate by 2025 . Also, per capita renewable water share has been declining from 853.5 $\mathrm{m} 3$ (2002) to $785.4 \mathrm{~m} 3$ (2007) and reached $722.2 \mathrm{~m} 3$
(2012). This is predicted to reach $534 \mathrm{~m} 3$ by 2030 (FAO, 2014).

Costaet al. (2007) indicated that the deficit irrigation strategies deliberately allow crops to sustain some degree of water deficit and sometimes, some yield reduction with a significant reduction of irrigation water. The classic deficit irrigation strategy (DI) implies that water is supplied at levels below full evapotranspiration (ETc) throughout the season.

Aeration Defined as the process by which air is mixed through water irrigation.

Goorahooet al. (2000) found that the concept of aerating the irrigation water increases the potential for the air to travel with water movement within the root zone. Physical, chemical, and biological soil characteristics that influence crop growth and yield depend on the relative proportions of the liquid and gas phases within the root zone. Generally, the incorporation of high efficiency aerogationin SSDI systems increased root zone aeration and can add value to grower investments in SSDI(Vyrlas at el. ,2014).

This study aimsat investigating the effect of deficit irrigation water, air injection and nitrogen fertilization under the sub-surface drip irrigation on carrot root 
production, growth parameters and Water Productivity (WP).

\section{Materials and Methods}

This experiment was carried out at the Experimental Farm of the Faculty of Agriculture, Benha University during the winter season of 2017/2018.

Particle size distribution of the soil used is as follow: s and $8.57 \%$, clay $41.86 \%$ and silt $49.57 \%$, therefore the soil texture as clayey soil. Soil moisture content was $62.5 \%$ at saturation point, while it was $57.35 \%$ at field capacity and $17.8 \%$ at welting point. So, the available moisture content is $39.55 \%$ by volume.

\subsection{Materials}

The main and sub- main lines were 63 and $25 \mathrm{~mm}$ diameter, respectively, of PVC pipe. $16 \mathrm{~mm}$ diameter built-in drip liner with $4 \mathrm{Lph} / 30 \mathrm{~cm}$, flow rates under 1 bar operating pressure was used.

Acentrifugal pump type E5300 with operating pressure head ranged between 13.5 - $32 \mathrm{~m}$ and corresponding discharge rates ranged from $500-100$ $\mathrm{L} / \mathrm{min}$. was used to connect directly by an electric motor of $2.25 \mathrm{~kW}$ power.

The air compressor used for air injection into the irrigationnet work was of $1 \mathrm{hp}$ and average flow rate of $10 \mathrm{~L} / \mathrm{min}$ at 1 bar pressure. The calibrated performance data of this compressor unit provided the ability to control the rate of air injected into the irrigation line to be $12 \%$ by volume of irrigation water, according to the recommendation of Bhattaraiet al. (2015),Abuarabet al. (2012) and Yuan at el. (2016). The nitrogen fertilization was carried out through three types of nitrogen resources i.e.

- Nitric Acid (HNO3) of $48 \% \mathrm{~N}$.

- Urea $(\mathrm{CO}(\mathrm{NH} 2) 2)$ of $46 \% \mathrm{~N}$.

- Ammonium nitrate $\left(\mathrm{NH}_{4} \mathrm{NO}_{3}\right)$ of $33.5 \% \mathrm{~N}$.

The carrot seeds (Daucuscarota, Umbelliferae) supplied by Sakata company.

The diameter of the harvested carrot roots was measured by digital caliper, whereas the length of carrot plants and roots was measured by ruler.

\subsection{The Experimental Design}

The experimental design was a split plot with three replicates. The two air injection treatments (with air injection and without air injection) were allotted as main plots, the three nitrogen fertilization types (nitric acid,urea and ammonium nitrate fertilization) were allotted as submain plots, while the three levels of deficit irrigation (I60\%, I80\% and $\mathrm{I} 100 \%$ ) were randomly allotted in subplots. The experimental area was $900 \mathrm{~m} 2(30 \times 30 \mathrm{~m})$ and area of each plot was $3 \mathrm{~m} 2$.

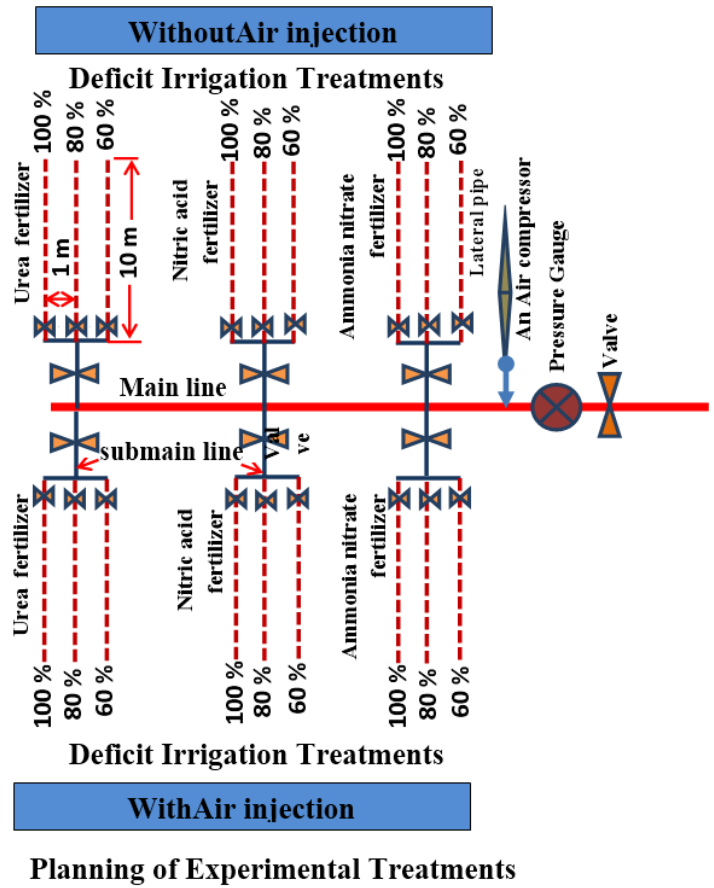

2.3 Amount of Water Applied per each Irrigation

Quantity of the applied irrigation water was determined before each irrigation for all treatments. The applied irrigation water depth for carrot plant was determined according to water consumed during irrigation intervals as the difference between soil moisture content at field capacity and the moisture content at the next irrigation. Twenty one percent $(21 \%)$ of the calculated water was added as a leaching requirement. The depth of water to be applied for each treatment was calculated according to the following equation:

Where

$$
\operatorname{Taw}=\left(\frac{\theta_{\text {f.c }}-\theta_{\text {b.i. }}}{100}\right) * \gamma_{\mathrm{s}} * \mathrm{D}_{\mathrm{rz}}
$$

Taw total available water depth, ( $\mathrm{mm})$.

$\theta_{\text {f.c }}$ volumetric soil water content at field capacity, $(\%)$.

$\theta_{\text {b.i. }}$ volumetric soil water content before

$\gamma_{\mathrm{s}}$ Soil specific bulk density.

$$
\text { irrigation, }(\%) \text {. }
$$

Drz the root zone depth, (mm).

The interval between successive irrigations was four days. The full irrigation treatment 100\% (I100\%) was equivalent of ETc of carrot crop. The deficit irrigation treatments $\mathrm{I} 80 \%$ and $\mathrm{I} 60 \%$ were 80 and 60 $\%$ from the full irrigation $100 \%$.

\subsection{Nitrogen Use Efficiency}

The nitrogen use efficiency (NUE) is the ratio of crop yield to the amount of applied $\mathrm{N}$, also called the partial factor productivity of applied $\mathrm{N}$ (PFPN).(Dobermann , 2005).

Sharma and Banik(2012) indicated that PFPN can be calculated from the equation: 


$$
\operatorname{PFPN}=\frac{Y_{N}}{F_{N}}
$$

Where

YN is crop yield $(\mathrm{kg} / \mathrm{fed})$.

$\mathrm{FN}$ is amount of fertilizer $\mathrm{N}$ applied ( $\mathrm{kg} / \mathrm{fed})$.

All types of fertilizers were added with irrigation water at a rate of 500 - $1000 \mathrm{~g} \mathrm{~m}$-3Nitrogen fertilizer, according tothe quantity of water applied per each irrigation and plant growth stage to be total of $70 \mathrm{~kg}$ / fed according to the recommendation of Hassan (1990).

\subsection{Production of Carrot}

The total carrot roots produced per Fadden was calculated as following:

$$
\begin{aligned}
\text { Carrot Production }(\mathrm{Kg} / \mathrm{fed}) \\
=\frac{\text { carrot root yield }(\mathrm{kg}) \times 4200}{\text { sample area }\left(\mathrm{m}^{2}\right)}
\end{aligned}
$$

\subsection{Water Productivity of carrot}

The water productivity of carrot yield was calculated as following:

$$
\begin{aligned}
& \text { Water productivity }\left(\mathrm{kg} / \mathrm{m}^{3}\right) \\
& =\frac{\text { biomass of carrot yield }(\mathrm{kg} / \mathrm{fed})}{\text { water applied }\left(\mathrm{m}^{3} / \mathrm{fed}\right)}
\end{aligned}
$$

Where, biomass inclusive plant plus root.

\section{Results and Discussion}

\subsection{Carrot root Length}

Data in table 1 show the effect of deficit irrigation, type of nitrogen fertilization and air injection on length of carrot root $(\mathrm{cm})$. The carrot root length was significantly affected by air injection treatments; however, it was not affected by fertilization treatments or deficit irrigation treatments. All the interactions between air injection $\mathrm{X}$ deficit irrigation, air injection $\mathrm{X}$ fertilization treatments, fertilization $X$ deficit Irrigation and air injection $X$ fertilization $\mathrm{X}$ deficit irrigation treatments were not significantly affect the carrot root length.

The highest value of the length of carrot root (19.80 $\mathrm{cm})$ was obtained by treatment of $80 \%$ deficit irrigation (I80\%), fertilization by $(\mathrm{CO}(\mathrm{NH} 2) 2)$ and air injection. The treatment of $100 \%$ deficit irrigation (I100\%), fertilization with (NH4NO3), plus air injection, resulted in the second highest root length i.e. $19.000(\mathrm{~cm})$

These results are in agreement with those of Carvalho et al. (2016) who found that the root carrot was influenced by different water depths (treatments).UNESP et al. (2015) found the bulb length, diameter and root length of radish crop increased due to increasing irrigation depth from $60 \%$ to $80 \%$ ETc. Dhungelet al. (2012) found that the use of aerated irrigation water (Oxygation) through root zone increased root volume.

\subsection{Carrot Root Diameter}

Data in Table 2 show the effect of deficit irrigation, type of nitrogen fertilization and air injection on diameter of carrot root $(\mathrm{mm})$. Results of statistical analysis indicated that, the carrot root diameter was not significantly affected by air injection treatments, deficit irrigation treatments, fertilization treatments, or by any interaction between each of them with other treatments.

The highest values of the diameter of carrot root (mm) were 42.153 and $41.260 \mathrm{~mm}$ obtained by $100 \%$ full irrigation (I100\%), fertilization with (NH4NO3) without air injection and $80 \%$ deficit irrigation (I80\%), fertilization $\mathrm{CO}(\mathrm{NH} 2) 2$ with air injection, respectively.

\subsection{Carrot production}

Data in Table 3showthe effects of deficit irrigation, nitrogen types and air injection on carrot yield production (ton/fed) during the growing season 2017-2018. No significant differences in carrot yield could be observed due to the deficit irrigation treatments. The root carrot weight was significantly increased by air injection treatments. Interactions between each of air injection $\mathrm{X}$ fertilization treatments, deficit irrigation $\mathrm{X}$ fertilization treatments and air injection $\mathrm{X}$ fertilization $\mathrm{X}$ deficit irrigation treatments had significant effects on carrot yield.

The highest values of the carrot root production (ton/fed) were obtained due to $60 \%$ deficit irrigation (I60\%), fertilization by ammonium nitrate fertilizer (NH4NO3)and air injection followed by $80 \%$ deficit irrigation (I80\%), fertilization by urea(CO(NH2)2) with air injection which resulted in 19.487 and 17.437 (ton/ fed), respectively. 
Table 1. Length of carrot root $(\mathrm{cm})$ as affected by air injection, fertilization type and deficit irrigation system under SSDI.

\begin{tabular}{|c|c|c|c|c|c|c|}
\hline \multirow{2}{*}{$\begin{array}{c}\text { Air Injection } \\
\text { treatment }\end{array}$} & \multirow{2}{*}{\multicolumn{2}{|c|}{ Fertilization treatment }} & \multicolumn{3}{|c|}{ Deficit Irrigation treatment } & \multirow{2}{*}{ Mean } \\
\hline & & & $\% 60$ & $\% 80$ & $\% 100$ & \\
\hline \multirow{3}{*}{ with } & \multicolumn{2}{|c|}{$\mathrm{CO}(\mathrm{NH} 2) 2$} & 18.967 & 19.800 & 17.933 & 18.900 \\
\hline & \multicolumn{2}{|c|}{ NH4NO3 } & 17.100 & 16.900 & 19.000 & 17.667 \\
\hline & \multicolumn{2}{|c|}{ HNO3 } & 16.467 & 16.733 & 17.967 & 17.056 \\
\hline \multirow{4}{*}{ Without } & \multicolumn{2}{|l|}{ mean } & 17.511 & 17.811 & 18.300 & 17.874 \\
\hline & \multicolumn{2}{|c|}{$\mathrm{CO}(\mathrm{NH} 2) 2$} & 15.833 & 16.733 & 16.533 & 16.366 \\
\hline & \multicolumn{2}{|c|}{ NH4NO3 } & 14.200 & 15.533 & 14.667 & 14.800 \\
\hline & \multicolumn{2}{|c|}{ HNO3 } & 15.367 & 15.567 & 16.633 & 15.856 \\
\hline \multirow{2}{*}{\multicolumn{3}{|c|}{$\begin{array}{c}\text { Mean } \\
\text { G. Mean }\end{array}$}} & 15.133 & 15.944 & 15.944 & 15.674 \\
\hline & & & 16.322 & 16.878 & 17.122 & \\
\hline \\
\hline \multicolumn{7}{|c|}{$\mathbf{C O}$ (NH2) $2 \quad 17.400 \quad 18.267$} \\
\hline \multicolumn{3}{|c|}{ NH4NO3 } & 15.650 & 16.217 & 16.833 & 16.233 \\
\hline \multicolumn{3}{|c|}{ HNO3 } & 15.917 & 16.150 & 17.300 & 16.456 \\
\hline LSD at 0.05: LSD & Factor Air Injection & 1.130 & & & & \\
\hline LSD for Factor Fe & zation & N.S & LSD & or Deficit & $=$ & N.S. \\
\hline LSD for Factor A & ajection X Fertilization & N.S & LSD & or Air Inje & f. Irri. $=$ & N.S. \\
\hline LSD for Factor Fe & X Def. Irri. & N.S. & LSD & tor Air Inje & t.X Def. Irri. = & N.S. \\
\hline
\end{tabular}

Table 2. Diameter of carrot root (mm) as affected by air injection, fertilization type and deficit irrigation systems under SSDI.

\begin{tabular}{|c|c|c|c|c|c|}
\hline \multirow{2}{*}{$\begin{array}{l}\text { Air Injection } \\
\text { treatment }\end{array}$} & \multirow{2}{*}{ Fertilization treatment } & \multicolumn{3}{|c|}{ Deficit Irrigation treatment } & \multirow{2}{*}{ Mean } \\
\hline & & $\% 60$ & $\% 80$ & $\% 100$ & \\
\hline \multirow{3}{*}{ with } & $\mathrm{CO}(\mathrm{NH} 2) 2$ & 37.800 & 41.260 & 40.860 & 39.973 \\
\hline & NH4NO3 & 38.233 & 36.977 & 37.360 & 37.523 \\
\hline & HNO3 & 35.003 & 31.247 & 37.343 & 34.531 \\
\hline \multirow[t]{2}{*}{ mean } & & 37.012 & 36.494 & 38.521 & 37.342 \\
\hline & $\mathrm{CO}(\mathrm{NH} 2) 2$ & 36.980 & 39.753 & 37.180 & 37.971 \\
\hline \multirow[t]{2}{*}{ without } & NH4NO3 & 38.503 & 34.213 & 42.153 & 38.290 \\
\hline & HNO3 & 37.397 & 37.437 & 38.417 & 37.750 \\
\hline Mean & & 37.627 & 37.134 & 39.250 & 38.004 \\
\hline G. Mean & & 37.319 & 36.814 & 38.886 & \\
\hline \multicolumn{6}{|c|}{ Mean of Fertilization X Deficit Irrigation } \\
\hline & $\mathrm{CO}(\mathrm{NH} 2) 2$ & 37.390 & 40.507 & 39.020 & 38.972 \\
\hline & NH4NO3 & 38.368 & 35.595 & 39.757 & 37.907 \\
\hline & $\mathrm{HNO} 3$ & 36.200 & 34.342 & 37.880 & 36.141 \\
\hline SD at 0.05: LSD for Fact & r Air Injection = & \multirow{2}{*}{\multicolumn{3}{|c|}{$\begin{array}{l}\text { LSD for Factor Fertilization } \\
\text { LSD for Factor Air Injection X Fertilization = }\end{array}$}} & N.S. \\
\hline SD for Factor Deficit Irri & $=\quad \mathrm{N} . \mathrm{S}$. & & & & N.S. \\
\hline SD for Factor Air Inject. & Def. Irri. $=$ N.S. & \multicolumn{3}{|c|}{ LSD for Factor Fert. X Def. Irri. = } & N.S. \\
\hline
\end{tabular}

Table 3. Production of carrot yield (ton/fed) as affected by air injection, fertilization type and deficit irrigation under SSDI.

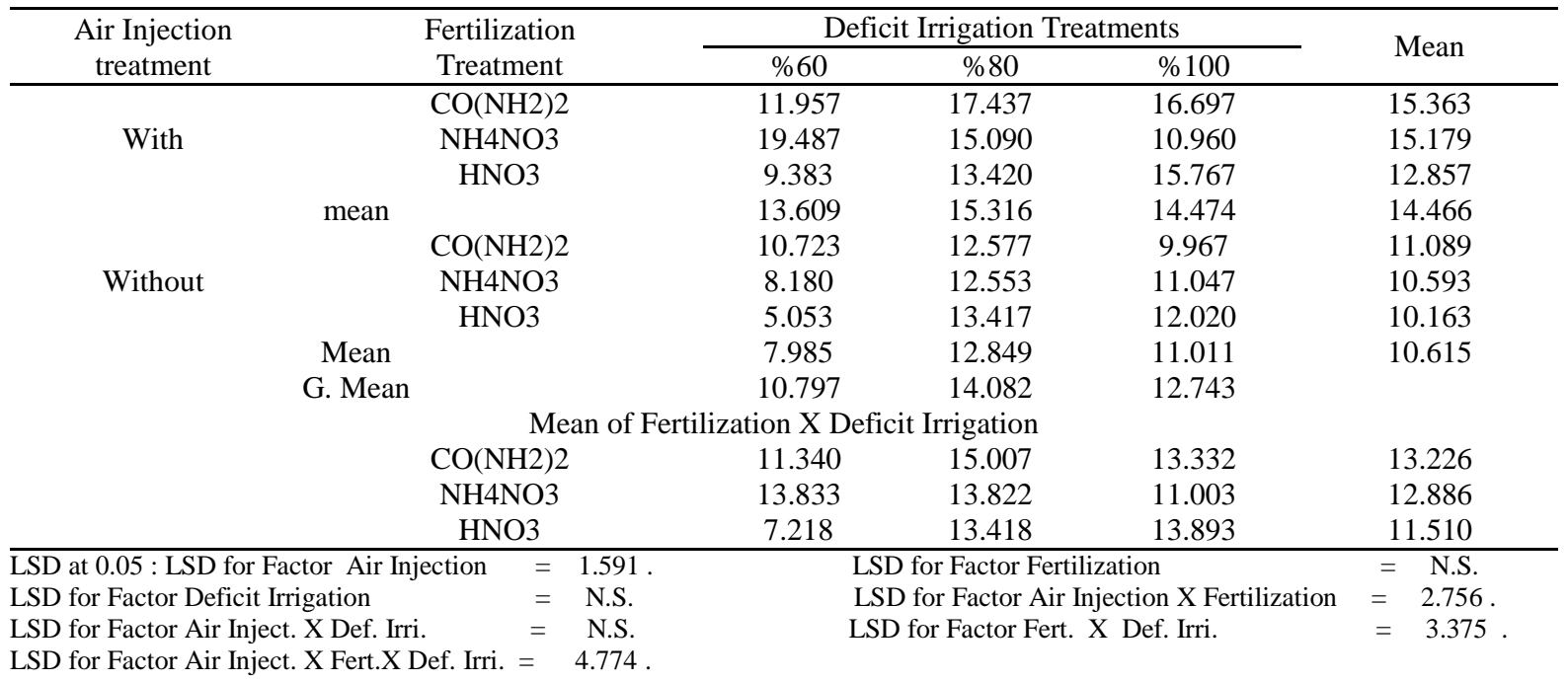


These results may be attributed to the suitable balance between air and soil moisturedue to air injection.Also, the deficit irrigation and air injection probably provided the root zone conditions favorite for activating the growth of carrot plant.

These results are in agreement with Liuet al. (2016) who found that the deficit irrigation (at $80 \%$ of FI) was the suitable mode of water and nitrogen management for Arabica coffee.Bhattaraiet al. (2006) found that the aeration(12\% air in water) increased the tomato fruit yield by $21 \%$ compared with the control (4.2 $\mathrm{kg}$ versus $3.7 \mathrm{~kg}$ per plant).Bhattaraiet al. (2004) found that increased aeration of the root zone in heavy clay soils caused beneficial effects to SSDI irrigated crops, irrespective of the soil water conditions, and could add value to grower investments in SSDI.

\section{Water Productivity of Carrot Yield}

Data in Table 4 show the effect of deficit irrigation, type of nitrogen fertilization and air injection on water productivity of carrot yield $(\mathrm{kg} / \mathrm{m} 3)$. Results indicate that, the water productivity carrot root weight $(\mathrm{kg} / \mathrm{m} 3)$ was significantly affected by air injection treatments, fertilization treatments , interaction between air injection $\mathrm{X}$ deficit irrigation, interaction between air injection Xnitrogen fertilization treatments, interaction between nitrogen fertilization $\mathrm{X}$ deficit irrigation and, interaction between air injection $\mathrm{X}$ nitrogen fertilization $\mathrm{X}$ deficit irrigation treatments, also No significantly affected by deficit irrigation treatments. In spite of the statistic alanalys is results, it could be observed a slight increasing trend in water productivity with deficit irrigation and it was more clear under air injection treatments. This increasing trend in water productivity was expected due to the less water applied under deficit irrigation

conditions with no significant effect on carrot production.

Therefore, the highest values of the water productivity of carrot yield $(\mathrm{kg} / \mathrm{m} 3)$ were obtained due to $60 \%$ deficit irrigation (I60\%), fertilization with(NH4NO3) and air injection and then followed by the treatment of same $60 \%$ deficit irrigation (I60\%), and air injection but except fertilization was byCO(NH2)2, which gave 185.189 and $101.376(\mathrm{~kg} / \mathrm{m} 3)$, respectively.

Table 4. water productivity of carrot $(\mathrm{kg} / \mathrm{m} 3)$ as affected by air injection, nitrogen fertilization type and deficit irrigation system under SSDI.

\begin{tabular}{|c|c|c|c|c|c|}
\hline \multirow{2}{*}{$\begin{array}{l}\text { Air Injection } \\
\text { treatment }\end{array}$} & \multirow{2}{*}{ Fertilization treatment } & \multicolumn{3}{|c|}{ Deficit Irrigation treatment } & \multirow{2}{*}{ Mean } \\
\hline & & $\% 60$ & $\% 80$ & $\% 100$ & \\
\hline & $\mathrm{CO}(\mathrm{NH} 2) 2$ & 101.376 & 87.979 & 61.127 & 83.494 \\
\hline \multirow[t]{2}{*}{ with } & NH4NO3 & 185.189 & 80.312 & 40.044 & 101.849 \\
\hline & HNO3 & 79.370 & 73.714 & 60.386 & 71.156 \\
\hline \multirow[t]{2}{*}{ mean } & & 121.978 & 80.668 & 53.852 & 85.499 \\
\hline & $\mathrm{CO}(\mathrm{NH} 2) 2$ & 93.045 & 69.309 & 32.784 & 65.046 \\
\hline \multirow[t]{2}{*}{ without } & NH4NO3 & 75.322 & 68.992 & 38.073 & 60.796 \\
\hline & HNO3 & 35.610 & 65.782 & 47.995 & 49.796 \\
\hline Mean & & 67.993 & 68.028 & 39.617 & 58.546 \\
\hline G. Mean & & 94.986 & 74.348 & 46.735 & \\
\hline \multicolumn{6}{|c|}{ Mean of fertilization $\mathrm{X}$ deficit irrigation } \\
\hline & $\mathrm{CO}(\mathrm{NH} 2) 2$ & 97.211 & 78.644 & 46.955 & 74.270 \\
\hline & NH4NO3 & 130.256 & 74.652 & 39.059 & 81.322 \\
\hline & HNO3 & 57.490 & 69.748 & 54.190 & 60.476 \\
\hline
\end{tabular}

LSD at 0.05 :LSD for Factor Air Injection $=9.684 . \quad$ LSD for Factor Fertilization $=11.860$.

LSD for Factor Deficit Irrigation $\quad=$ N.S. $\quad$ LSD for Factor Air Injection X Fertilization = 16.773.

LSD for Factor Air Inject. X Def. Irri. = 16.773. $\quad$ LSD for Factor Fert. X Def. Irri. $\quad=20.542$.

LSD for Factor Air Inject. X Fert.X Def. Irri. = 29.051

In general, it could be concluded that, water productivity was increased with air injection as well as with deficit irrigation under all the tested types of $\mathrm{N}$-fertilizers. The quantity of water added at $\mathrm{I} 60 \%$, I80\% and $\mathrm{I} 100 \%$ treatments were $394.548,526.008$ and $657.552 \mathrm{~m} 3 / \mathrm{fed}$, respectively.

3.5 Effect of air injection treatments on the partial factor productivity of nitrogen (PFPN):

Data in Table 5 and Figure 1 show that, the partial factor productivity of nitrogen (PFPN, $\mathrm{kg}$ of carrot roots $/ \mathrm{kg}$ of applied $\mathrm{N}$ ) was highly increased by air injection treatments. The highest values of the partial factor productivity of nitrogen 215.168 and $212.591(\mathrm{~kg}$ carrot roots $/ \mathrm{kg} \mathrm{N})$ were obtained by nitrogen fertilization with urea $\mathrm{CO}(\mathrm{NH} 2) 2$ and nitrogen fertilization with ammonium nitrate (NH4NO3) under air injection treatments, respectively. The percentage of increase in the partial factor productivity of nitrogen due to air injection treatment was $36.3 \%$ compared with the no air injection treatment. 
Table 5. The partial factor productivity of nitrogen (PFPN, $\mathrm{kg}$ root carrot $/ \mathrm{kg} \mathrm{N}$ ) as affected by air injection treatments and fertilization type under SSDI.

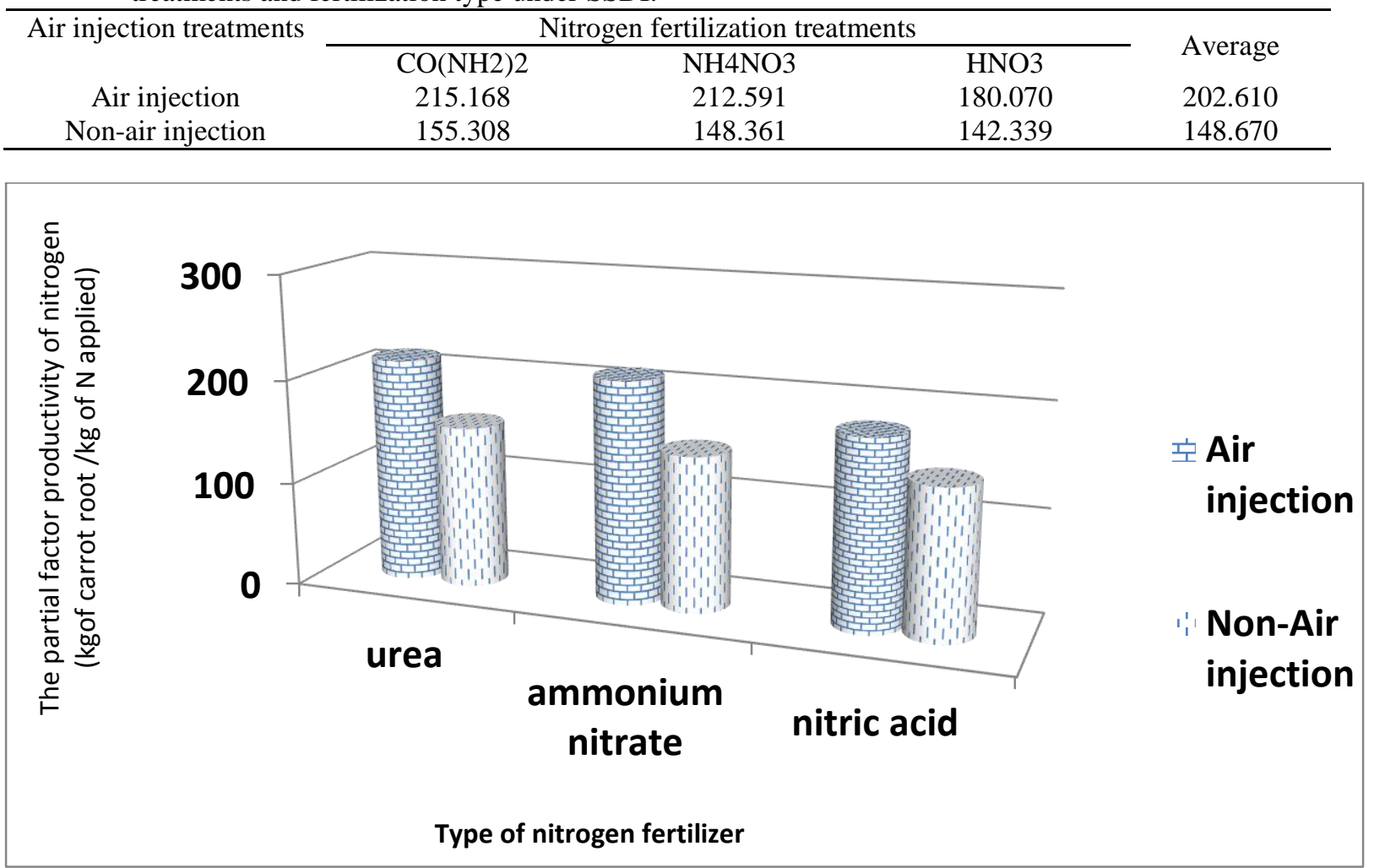

Figure 1.Therelationship between nitrogen fertilization types and the partial factor productivity of nitrogen (PFPN, Kg of carrot root $/ \mathrm{Kg}$ of $\mathrm{N}$ applied) under air injection and no air injection condition.

3.6 Effect of air injection and deficit irrigation level on the partial factor productivity of nitrogen (PFPN): Data in Figure 2 show that the partial factor productivity of nitrogen was higher for all air injection under deficit irrigation levels. The highest values of the partial factor productivity of nitrogen were
272.927 and 244.216 ( $\mathrm{kg}$ root carrot $/ \mathrm{kg} \mathrm{N}$ ) obtained under air injection treatment from deficit irrigation $60 \%$ (I60\%) with nitrogen fertilizer of ammonium nitrate (NH4NO3) and deficit irrigation $80 \%$ (I80\%) with nitrogen fertilizer of urea $\mathrm{CO}(\mathrm{NH} 2) 2$, respectively.

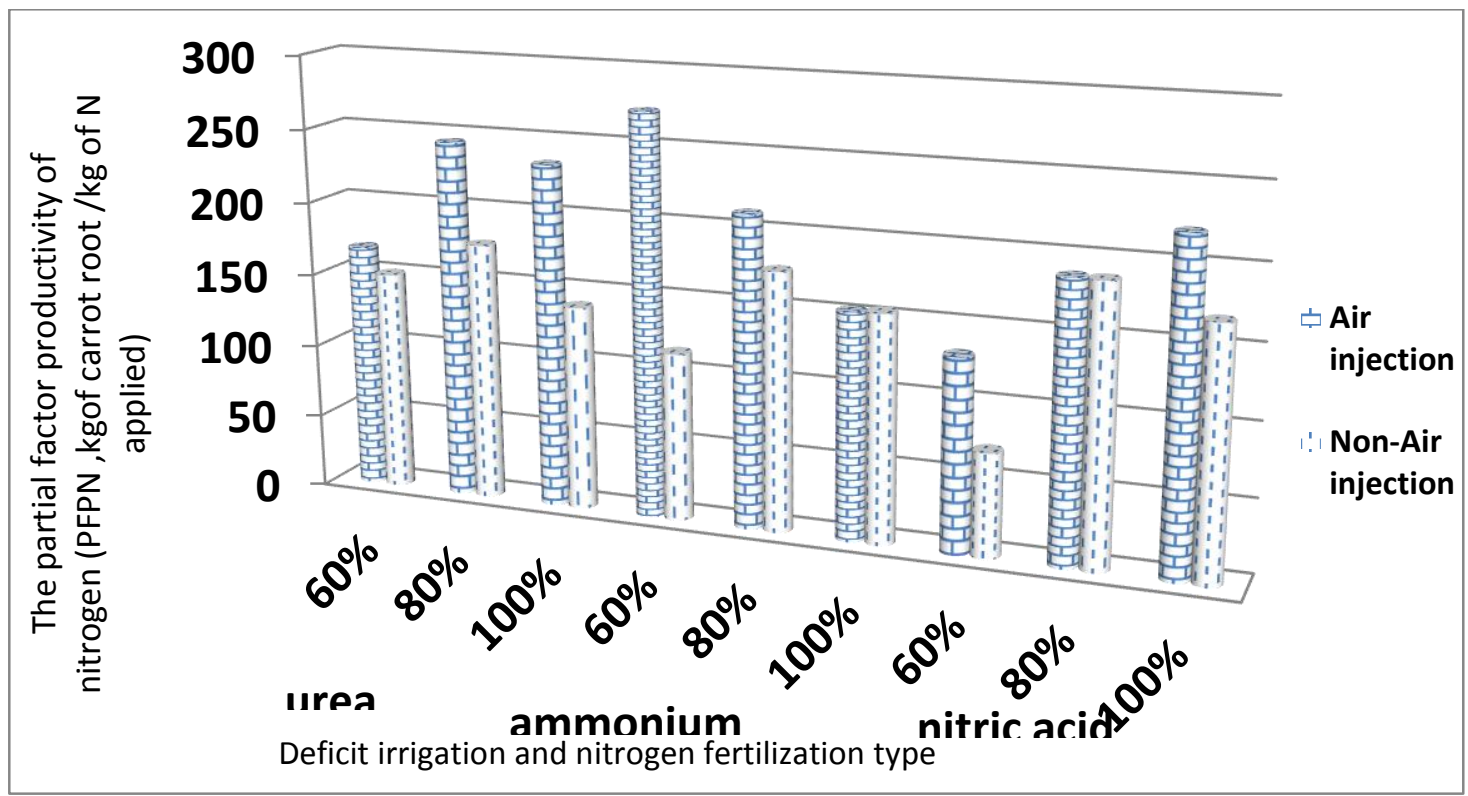

Figure2. The relationship between deficit irrigation levels, nitrogen fertilization types and the partial factor productivity of nitrogen (PFPN, $\mathrm{Kg}$ of carrot root $/ \mathrm{Kg}$ of $\mathrm{N}$ applied) with air injection treatments. 


\section{Conclusions}

The objectives of this study were to evaluate the effect of deficit irrigation, air injection and nitrogen fertilization type on water productivity under subsurface drip irrigation. The results of this study showed that :

1- Deficit irrigation strategy is useful to save the water for the agricultural purposes.

2- Air injection technique is essential to increase the production and water productivity of the crops.

3- The deficit irrigation is useful for increasing the root crop production.

4- An increase percentage of $36.3 \%$ in the partial factor productivity of nitrogen occurred due to air injection compared with noair injection treatment under all deficit irrigation and all types of fertilizers.

5- The best production and water productivity of the carrot crop were obtained due to $160 \%$ and $\mathrm{I} 80 \%$ deficit irrigation with air injection technique.

6- The average length of carrot roots was significantly affected by air injection.

7- The carrot rootdiameter did not significantly affectedbythe deficit irrigation with air injection orwithout air injection treatments.

Acknowledgements

This research was funded, in part, by the Egyptian "Academy of scientific Research and Technology, ASRT".

\section{References}

Abuarab, M.; Mostafa E. and Ibrahim M.(2012).effect of air injection under subsurface drip irrigation on yield and water use efficiency of corn in a sandy clay loam soil. Journal of Advanced Research 4, 493-499.

Bhattarai, S. P. ; Huber S. and Midmore D. J. (2004). Aerated subsurface irrigation water gives growth and yield benefits tozucchini, vegetable soybean and cotton in heavy clay soils.Ann. appl. Biol. 144:285-298.

Bhattarai S.P., ; Balsys R.J., ; Eichler P., ; MidmoreD.J. and WassinkD. (2015). dynamic changes in bubble profile due to surfactant and tape orientation of emitters in drip tape during aerated water irrigation. International Journal of Multiphase Flow 75,137-143.

Bhattarai S. P., Pendergast L. and Midmore D. J. (2006). root aeration improves yield and water use efficiency of tomato in heavy clay and saline soils. (Science Direct) ScientiaHorticulturae108, 278288.

Carvalho D. F. d., ; NetoD. H. de O., ; Felix L. F., ; Guerra J. G. M. and Salvador C. A.(2016). Yield, water use efficiency, and yield response factor in carrot crop under different irrigation depths. CROP PRODUCTION.Ciência Rural, Santa Maria, v.46, n.7, p.1145-1150.
Costa J. M., ; OrtunoM. F. and Chaves M. M.(2007). deficit irrigation as a strategy to save water: physiology and potential application to horticulture.Journal of Integrative Plant Biology 49 (10): 1421-1434.

Dakkak A. (2017). egypt's water crisis - recipe for disaster.July 7, 2018 Environment, Middle East, Pollution, Water.

Dhungel J., ; Bhattarai S.P. and Midmore D. J. (2012). Aerated water irrigation (oxygation) benefits to pineapple yield, water use efficiency and crop health. Adv. Hort. Sci., 26(1): 3-16.

Dobermann A. (2005). .Nitrogen Use Efficiency State of the Art.Agronomy \& Horticulture -Faculty Publications. 316.

FAO (2018). Water accounting forwater governance andsustainable development.

FAO (2014). AQUASTAT Database. Retrieved September 29, 2014, from Food and Agriculture Organization of the United Nations: http://www.fao.org/nr/water/aquastat/main/index. stm.

Goorahoo D., ; Adhikari D., ; Carstensen G. and Zoldoske D. (2000). Impact of aerated subsurface irrigation water on the growth and yield of crops. Center for Irrigation Technology, California State University, Fresno. 5370 N. Chestnut Fresno, CA 93740.

Hassan A. A. (1990). Rooting Vegetables. Al Dar Al Arabia for Publishing and Distribution, Nasr City,Cairo,1990, ISBN 977-1475-47-9. Page 242.

Liu X., ; Li F., ; Zhang Y. and Yang Q. (2016). Effects of deficit irrigation on yield and nutritional quality of arabica coffee (coffeaarabica) under different $\mathrm{n}$ rates in dry and hot region of southwest china. Agricultural Water Management 172 1-8.

Osman R., ; Ferrari E. and McDonald S. (2015). Water Scarcity and Irrigation Efficiency in Egypt .international conference of agricultural economists(ICAE)29th, Milan.

Sharma R. C. and Banik P. (2012). Effect of integrated nutrient management on baby corn-rice cropping system: economic yield, system productivity, nutrient-use efficiency and soil nutrient balance. Indian Journal of Agricultural Sciences 82:220-4.

UNESP, ; UNIFENAS, ; UNESP and UNIVEF (2015). The effects of different irrigation depths on radish crops. Irriga, Botucatu, Edição Especial, 20 anosIrriga +50 anos FCA, p. 150-159, ISSN 1808-3765.

Vyrlas P., ; Sakellariou-MakrantonakiM. and KalfountzosD. (2014).aerogation: crop root-zone aeration through subsurface drip irrigation system. WseasTransactions on Environment and Development. E-ISSN: 2224-3496. Volume 10.

Yuan L., ; Wenquan N., ; JingweiW., ; JianX., ; MingzhiZ. and Kangyong L. (2016). Review on advances of airjection irrigation. Int $\mathrm{J}$ Agric\&BiolEng.. Vol. 9 No.2. 
تأثير الري الناقص وحقن الهواء والتسميد النيتروجيني على الأنتاجية المائية لمصصول الجزر تحت نظام الري بالتنقيط تحت السطحي.

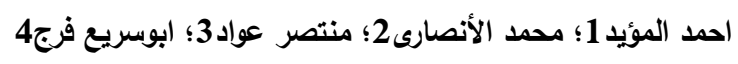

1: طالب دراسات عليا، 2: أستاذ ؛3: استاذ م. ؛ 4: مدرس هندسة النظم الزراعية والحيوية بكلية النزاعة جامعة بنها

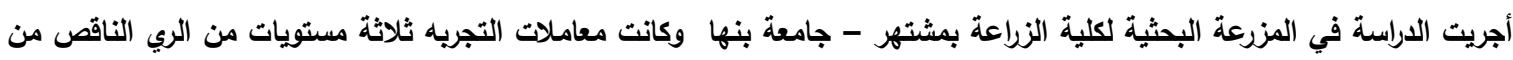

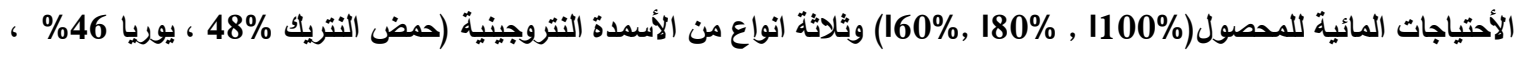

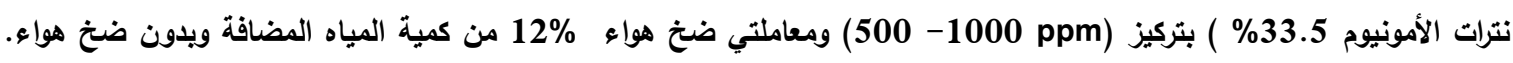

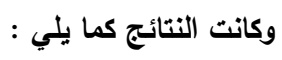
-أعلى قيم لأنتاجية محصول الجزر (طن / فدان) اعطيت بالمعاملة 60\% ري ناقص (160\%) و 160 و سماد نترات الأمونيوم 33.5\% وحقن

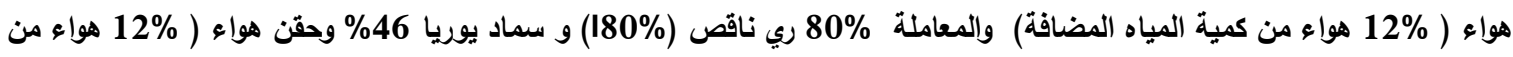

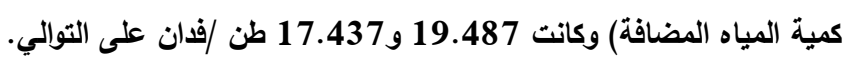

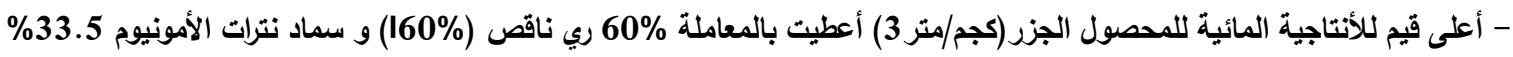

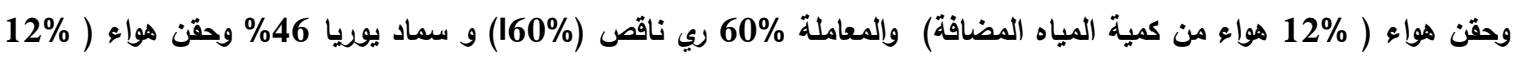

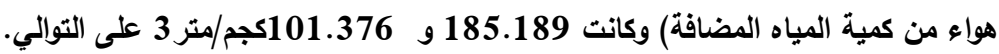

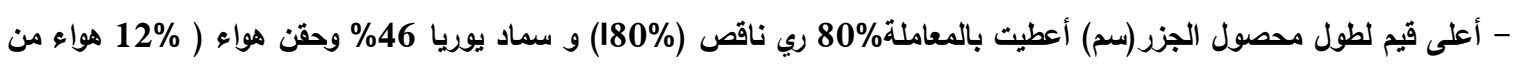
كمية مياه الري المضافة) والمعاملة 100\% ري ناقص (100\%)

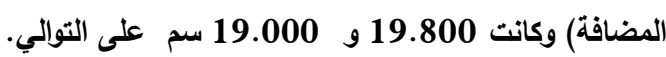

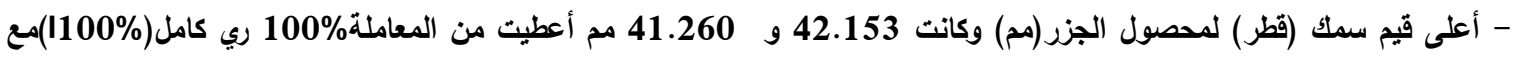

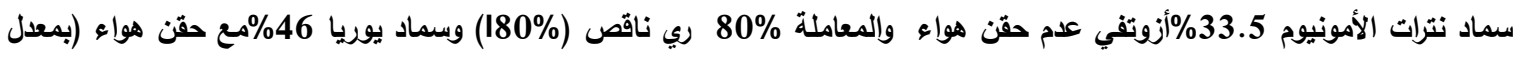
حقن هواء12\% من كمية مياه الري المضافة) على التوالي.

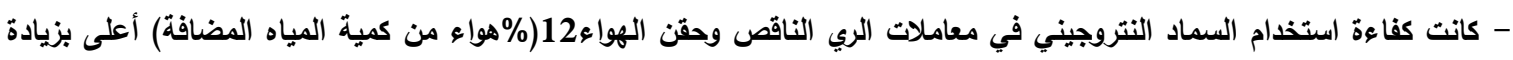
36.3\% مقارنة بمعاملات الري الناقص بدون حقن هواء. 